\title{
A dysprosium-based metal-organic framework: Synthesis, characterization, crystal structure and interaction with calf thymus-DNA and bovine serum albumin
}

\author{
BIPLAB MONDAL $^{\mathrm{a}}$, BUDDHADEB SEN ${ }^{\mathrm{a}}$, ENNIO ZANGRANDO ${ }^{\mathrm{b}}$ and \\ PABITRA CHATTOPADHYAY ${ }^{\mathrm{a}, *}$ \\ a Department of Chemistry, Burdwan University, Golapbag, Burdwan 713104, India \\ ${ }^{b}$ Department of Chemical and Pharmaceutical Sciences, Via Licio Giorgieri 1, 34127 Trieste, Italy \\ e-mail: pabitracc@yahoo.com
}

MS received 9 November 2013; revised 6 February 2014; accepted 16 February 2014

\begin{abstract}
A dysprosium-based metallo-organic framework (MOF) containing calcium ions formulated as $\left\{\right.$ Dy $\left.(\text { pyda })_{3} \mathrm{Ca}_{1.5}\left(\mathrm{H}_{2} \mathrm{O}\right)_{6}\right\} \cdot 5.5 \mathrm{H}_{2} \mathrm{O}(\mathbf{1})\left(\mathrm{H}_{2}\right.$ pyda $=$ pyridine-2,6-dicarboxylic acid $)$ was solvothermally synthesized in ethanolic medium and characterized by physico-chemical and spectroscopic tools. A detailed structural analysis of the solid state structure of $\mathbf{1}$ by single crystal X-ray diffraction study showed a tricapped trigonal prism geometry for lanthanide in the $\left[\mathrm{Dy}(\mathrm{pyda})_{3}\right]^{3-}$ fragment. The mode of interaction of 1 with calf thymusDNA and with protein bovine serum albumin (BSA) was investigated by using absorption and emission spectroscopic tools. The apparent association constant of complex 1 with CT-DNA was deduced from an absorption spectral study $\left(K_{\mathrm{b}}=4.08 \times 10^{4} \mathrm{M}^{-1}\right)$. Spectral and viscosity measurements indicated a groove-binding mode of 1 with CT-DNA, and from spectroscopic study the formation of a metal complex-BSA adduct was assumed to be the result of the interaction of $\mathbf{1}$ with BSA.
\end{abstract}

Keywords. Metallorganic framework (MOF); dysprosium complex; crystal structure; DNA binding; BSA binding.

\section{Introduction}

The current revolutionary increase in the number of synthesized and structurally characterized metalorganic coordination frameworks (MOFs) reflects the demand for new materials with predesigned functionalities. ${ }^{1-3}$ Structures of polymeric networks and their properties are largely determined by a suitable combination of metal ions and polydentate organic linkers. The correct choice of building blocks together with a proper synthetic strategy can lead to networks of different branching, topologies and dimensionality. ${ }^{4-6}$ By virtue of the unique properties originating from their $4 \mathrm{f}$ electron configurations, ${ }^{7-10}$ lanthanides are often utilized as MOFs nodes because of their propensity to high coordination numbers and inherent luminescence, which are essential for the formation of unusual network topologies and luminescent material, respectively. ${ }^{11-13}$ Usually lanthanide ions have high affinity for hard donor atoms such as oxygen and chelating ligands containing oxygen-nitrogen donors. There-

*For correspondence fore, such ligands are good sensitizers for lanthanide ions in the construction of lanthanide-based MOFs.

Taking into account the above facts and as part of our continuous interest in the interaction of metal complexes with calf thymus-DNA (CT-DNA), ${ }^{14-18}$ herein we report the synthesis, structural characterization of a newly designed complex, $\left\{\mathrm{Dy}(\text { pyda })_{3} \mathrm{Ca}_{1.5}\left(\mathrm{H}_{2} \mathrm{O}\right)_{6}\right\}$. $5.5 \mathrm{H}_{2} \mathrm{O}(\mathbf{1})$ (where $\mathrm{H}_{2}$ pyda = pyridine-2,6-dicarboxylic acid, scheme 1), which was duly characterized by physico-chemical and spectroscopic tools along with its detailed structure using single crystal X-ray crystallography. The study of the interaction of complex 1 with CT-DNA and with bovine serum albumin (BSA) was performed. The interaction with CT-DNA was investigated with the help of absorption and emission spectroscopic tools. In order to establish the association mode of this molecule to DNA, the binding $\left(K_{\mathrm{b}}\right)$ and the quenching constant $\left(K_{\mathrm{q}}\right)$ of the complex with the double-helix have been determined from UV-Vis study and fluorescence displacement experiments using ethidium bromide as spectral probe. On the other hand, the strong binding propensity of $\mathbf{1}$ to interact with BSA was examined using absorption-fluorescence spectroscopy, which allowed to detect the fluorescence quenching of 


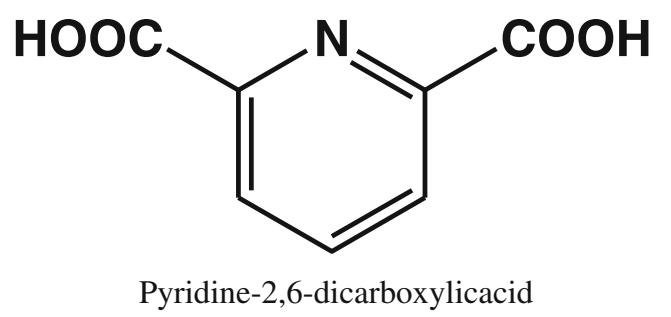

Scheme 1. Schematic structural representation of pyridine2,6-dicarboxylic acid (H2pydca).

BSA by complex 1 due to the formation of a metal complex-BSA species.

\section{Experimental}

\subsection{Materials and physical measurements}

Chemicals and reagents used for the synthesis were obtained from commercial sources. Solvents were distilled before use and treated with an appropriate drying agent. Elemental $(\mathrm{C}, \mathrm{H}, \mathrm{N})$ analyses were performed on a Perkin Elmer-model 2400 elemental analyser. IR spectrum of $\mathbf{1}$ was recorded on a Perkin-Elmer FTIR model RX1 spectrometer ( $\mathrm{KBr}$ disc, 4000$300 \mathrm{~cm}^{-1}$ ). Room temperature magnetic susceptibility was recorded by using a vibrating sample magnetometer PAR 155 model. Thermo-gravimetric analysis (TGA) was performed on a Perkin-Elmer Diamond TG/DTA analyser. Electronic absorption spectra were recorded on a JASCO UV-Vis/NIR spectrophotometer model V-570. Fluorescence spectra complex bound to DNA were obtained at an excitation wavelength of $522 \mathrm{~nm}$ with Hitachi-4500 fluorimeter.

\subsection{Synthesis of complex 1}

Solvothermal process was carried out to synthesize this complex as it follows. The organic moiety, pyridine2,6-dicarboxylic acid ( $\mathrm{H}_{2}$ pydca, $\left.501 \mathrm{mg}, 3.0 \mathrm{mmol}\right)$ was dissolved in dry ethanol by stirring the mixture for $15 \mathrm{~min}$. A volume of $1.0 \mathrm{mmol}$ of $\mathrm{Dy}\left(\mathrm{NO}_{3}\right)_{3} \cdot 6 \mathrm{H}_{2} \mathrm{O}$ (456 mg) was dissolved in a minimum quantity of water and this aqueous solution was added dropwise to the ethanolic $\mathrm{H}_{2}$ pydca solution under stirring condition. Then, the resulting solution mixture was refluxed for $2 \mathrm{~h}$ and calcium chloride $\left(\mathrm{CaCl}_{2} .2 \mathrm{H}_{2} \mathrm{O}, 147 \mathrm{mg}\right.$, $1.0 \mathrm{mmol}$ ) was added under stirring condition. The mixture was kept in teflon reaction chamber for $32 \mathrm{~h}$ at a temperature of $130^{\circ} \mathrm{C}$ and filtered off for collecting clear filtrate. This filtrate was kept aside for slow evaporation at room temperature. After a few days, a fine microcrystalline compound was separated out and washed thoroughly with water, ethanol and dried in vacuo over silica gel desiccator. Single crystals of $\mathbf{1}$ suitable for X-ray diffraction study were also obtained by slow evaporation of this solution. The dried material was used also for elemental analysis and characterization using physico-chemical and spectroscopic tools.

$\left\{\left[\right.\right.$ Dy $\left.(\text { pyda })_{3} \mathrm{Ca}_{1.5}\left(\mathrm{H}_{2} \mathrm{O}\right)_{6}\right\} \cdot 5.5 \mathrm{H}_{2} \mathrm{O}: \quad$ Yield: $\quad 70 \%$ $(0.6391 \mathrm{~g}) ; \mathrm{C}_{21} \mathrm{H}_{32} \mathrm{Ca}_{1.50} \mathrm{DyN}_{3} \mathrm{O}_{22.50}$ : Anal. Found: $\mathrm{C}$, 27.74; H, 3.55; N, 4.62; Calc.: C, 27.58; H, 3.14; N, 4.60. IR: the $3252 \mathrm{~cm}^{-1}$ band was assigned as characteristic peak of water $\mathrm{OH}$ bond, $v_{\mathrm{C}=\mathrm{N}} 1471, v_{\mathrm{asCOO}} 1608$, $v_{\mathrm{C}=\mathrm{O}} 1565 \mathrm{~cm}^{-1}$. Magnetic moment ( $\mu$, B.M.): 10.64 .

\section{$2.3 X$-ray crystal structure analysis}

Diffraction data for structural characterization of $\mathbf{1}$ were collected at room temperature (293(2) K) on a Brucker Kappa CCD imaging plate mounted on a Nonius FR591 rotating anode $(\mathrm{Cu}-\mathrm{K} \alpha$ radiation, $\lambda=1.54180 \AA)$. Cell refinement, indexing and scaling of the data set were carried out using Denzo and Scalepack. ${ }^{19}$ The structure was solved by Patterson and Fourier analyses ${ }^{20}$ and refined by the full-matrix least-squares method based on $F^{2}$ with all observed reflections. ${ }^{20}$ Based on Fourier peaks, occupancy of one lattice water molecule was fixed at $0.5, \mathrm{H}$ atoms of all water molecules were not assigned. All the calculations were performed using the WinGX System, Ver 1.80.05. ${ }^{21}$ Crystal data and details of data collection and refinement for $\mathbf{1}$ are summarized in table 1 .

\subsection{DNA binding experiments}

Tris- $\mathrm{HCl}$ buffer solution ( $\mathrm{pH}$ 7.2) used in all the experiments involving CT-DNA was prepared using deionized and sonicated HPLC grade water (Merck). The CT-DNA used in the experiments was checked to be sufficiently free from protein as the ratio of UV absorbance of DNA solution in Tris- $\mathrm{HCl}$ at 260 and $280 \mathrm{~nm}\left(\mathrm{~A}_{260} / \mathrm{A}_{280}\right)$ was around 1.9. ${ }^{22}$ Concentration of DNA was estimated by using the extinction coefficient $\left(6600 \mathrm{M}^{-1} \mathrm{~cm}^{-1}\right)$ at $261 \mathrm{~nm}^{23}$ and stock solution of DNA was always stored at $4^{\circ} \mathrm{C}$. Stock solution of the complex was prepared by dissolving it in $2 \mathrm{~mL}$ of DMSO and diluted with Tris- $\mathrm{HCl}$ buffer to get the required concentration for all the experiments. Absorption spectral titration experiment was performed by maintaining constant the complex concentration and varying the CT-DNA concentration. To eliminate the 
Table 1. Crystal data and details of refinement for compound 1.

\begin{tabular}{lc}
\hline Empirical Formula & $\mathbf{C}_{\mathbf{2 1}} \mathbf{H}_{\mathbf{3 2}} \mathbf{C a}_{\mathbf{1 . 5 0}} \mathbf{D y}_{\mathbf{3}} \mathbf{O}_{\mathbf{2 2 . 5 0}}$ \\
\hline Formula Weight & 909.12 \\
Crystal System & Monoclinic \\
Space group & $P$ 2/c \\
$a(\AA)$ & $16.231(3)$ \\
$b(\AA)$ & $9.431(3)$ \\
$c(\AA)$ & $24.107(3)$ \\
$\beta($ deg $)$ & $108.22(3)$ \\
Volume $\left(\AA^{3}\right)$ & $3505.2(14)$ \\
Radiation type & $C u-K_{\alpha}$ \\
Wavelength $(\AA)$ & 1.5418 \\
Measurement temperature & $293(2)$ \\
$Z$ & 4 \\
$\rho_{\text {calc }}\left(\mathrm{g} / \mathrm{cm}^{3}\right)$ & 1.723 \\
$F(000)$ & 1820 \\
$\theta$ range $($ deg$)$ & $4.03-65.45$ \\
Goodness-of-fit & 1.006 \\
Data/restraints/parameters & $5642 / 0 / 445$ \\
Final R1, wR2 $[I<2 \sigma(I)]$ & $0.0620,0.1777$ \\
$R$ indices (all data) & $0.0828,0.1888$ \\
Residuals e. $\AA^{-3}$ & $2.228,{ }^{a}-1.448$ \\
\hline
\end{tabular}

a at $1.96 \AA$ from O8w, likely a fraction of disordered water molecule

absorbance of DNA itself, equal amount of CT-DNA was added to the reference solution.

In the ethidium bromide (EB) fluorescence displacement experiment, $5.0 \mu \mathrm{L}$ of the EB Tris- $\mathrm{HCl}$ solution $\left(1.0 \mathrm{mmol} \mathrm{L}^{-1}\right)$ was added to $1.0 \mathrm{~mL}$ of DNA solution (at saturated binding levels), ${ }^{24}$ stored in the dark for $2.0 \mathrm{~h}$. Then, the solution of complex 1 was titrated into the DNA/EB mixture and diluted with Tris- $\mathrm{HCl}$ buffer to $5.0 \mathrm{~mL}$ to get the solution with the appropriate complex/CT-DNA mole ratio. Before taking measurements, the mixture was shaken up and incubated at room temperature for $30 \mathrm{~min}$. Fluorescence spectra of EB bound to DNA were obtained in the fluorimeter with $\lambda_{\text {ex }}$ of $522 \mathrm{~nm}$.

To adjudge the binding mode (groove/intercalative) of 1 with DNA, viscosity measurement method was used by employing Ostwald's viscometer. Titrations were carried out in the viscometer by adding complex $1(0.5-3.5 \mu \mathrm{M})$ to the CT-DNA solution $(5.0 \mu \mathrm{M})$. Viscosity values of the solutions were calculated from the observed flow time of CT-DNA-containing solution corrected from the flow time of buffer alone $\left(t_{0}\right)$, $\eta=t-t_{0}$. The obtained data were used to plot the $\left(\eta / \eta_{0}\right)^{1 / 3}$ versus the ratio of the concentration of $\mathbf{1}$ and CT-DNA, where $\eta$ is the viscosity of the CT-DNA solution in presence of $\mathbf{1}$ and $\eta_{0}$ is the viscosity of the CT-DNA solution only.

\subsection{Protein (bovine serum albumin) binding experiments}

A similar experiment was performed with BSA, the only difference being the concentration of BSA that was kept constant throughout the experiment. Figure 11 shows the gradual increase of absorbance with increasing concentration of complex $\mathbf{1}$. In order to confirm that the observed absorption change in the spectrum was not due to experimental errors, a baseline correction was performed for all the measurements. The results clearly indicate an interaction between complex $\mathbf{1}$ and BSA.

Fluorescence quenching study of BSA was carried out in similar fashion keeping fixed the concentration of BSA in solution while increasing the concentration of complex 1. Baseline correction was carried out for all the measurements to get rid of probable scattering effects due to the suspended nature of complex 1 in aqueous medium. This ensures that fluorescence quenching occurs only for the interaction between BSA and complex $\mathbf{1}$.

\section{Result and discussion}

\subsection{Synthesis and characterization}

The title compound $\mathbf{1}$ was synthesized and isolated through solvothermal process by using dysprosium nitrate hexahydrate, pyridine-2,6-dicarboxylic acid $\left(\mathrm{H}_{2}\right.$ pydca $)$ and calcium chloride in a molar ratio of $1: 3: 1$, respectively in a teflon reaction vessel at a temperature of $130^{\circ} \mathrm{C}$. Micro-analytical data confirm the composition of the complex. Paramagnetic nature of compound $\mathbf{1}$ was established by its magnetic moment $\mu$ that was measured to be 10.45 B.M. at room temperature.

\subsection{Structural analysis of $\mathbf{1}$}

The X-ray structural analysis of $\mathbf{1}$ revealed that the independent unit comprises a $\left[\mathrm{Dy}(\mathrm{pyda})_{3}\right]^{3-}$ moiety, three calcium(II) ions located at special crystallographic positions (see below), and 11.5 water molecules, of which 5.5 are lattice species. The ORTEP diagram of the lanthanide complex (figure 1) shows that the $\mathrm{Dy}^{3+}$ ion is nine-coordinated by three pyridine2,6-dicarboxylates anions, where Dy-O bond lengths range from $2.397(5)$ to $2.438(5) \AA$, while the Dy$\mathrm{N}$ distances are slightly longer (2.469(7)-2.496(6) $\AA)$. A selection of bond distances is reported in 


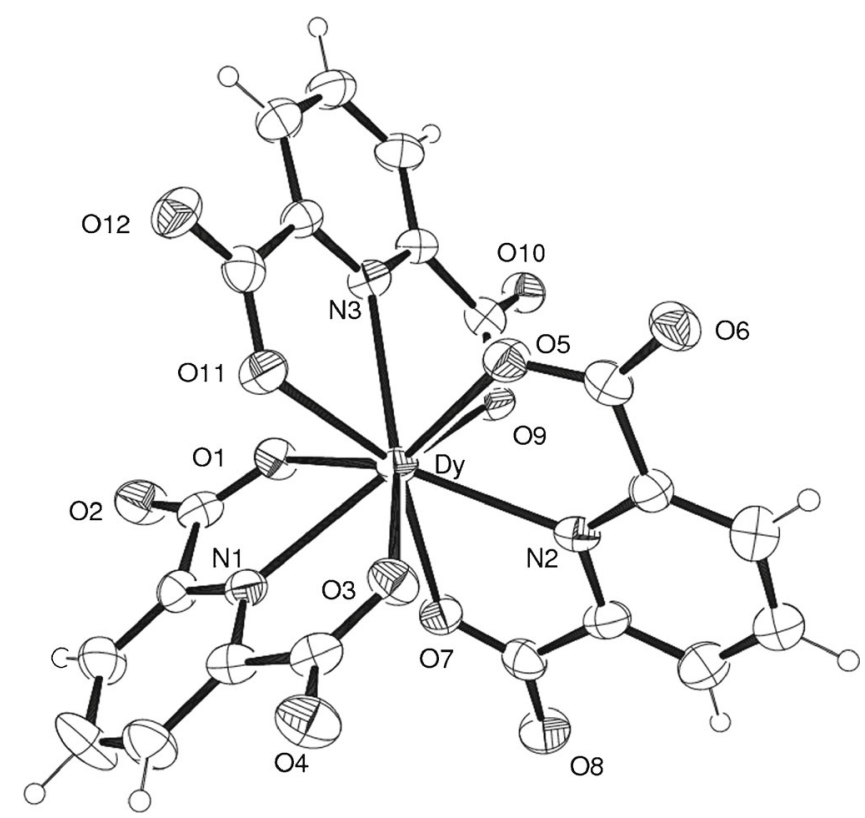

Figure 1. ORTEP diagram (35\% probability ellipsoid) of the $\left[\mathrm{Dy}(\mathrm{pyda})_{3}\right]^{3-}$ anionic moiety with atom label scheme.

table 2. This tricapped trigonal prism geometry and the relative coordination distances are similar to those found for dysprosium ion in $\left[\mathrm{Dy}_{2}(\mathrm{pyda})_{3}\left(\mathrm{H}_{2} \mathrm{O}\right)_{4}\right]_{n}{ }^{25}$ and $(\operatorname{ImH})_{3}\left[\mathrm{Dy}(\mathrm{pyda})_{3}\right]^{.26}(\mathrm{imH}=$ imidazolium ion $)$ frameworks.

Of calcium ions, $\mathrm{Ca}(1)$ is located on a two-fold axis and is eight-coordinated by four water molecules and four oxygen donors from different pyda ligands, resulting in a square antiprismatic geometry (figure 2). On the other hand, $\mathrm{Ca}(2)$ and $\mathrm{Ca}(3)$ ions are located on an inversion centre and both are six-coordinated by four water molecules and two oxygen donors from pyda ligands in trans position so that they assume, octahedral geometry (figure 3 ). It is noteworthy that $\mathrm{Ca}(1)-\mathrm{O}$ bond distances are $0.1-0.2 \AA$ longer than the $\mathrm{Ca}(2)-\mathrm{O}$ and

Table 2. Coordination bond distances $(\AA)$ of $\mathbf{1}^{\text {a }}$.

\begin{tabular}{llll}
\hline Dy-O(1) & $2.438(5)$ & Dy-O(11) & $2.408(5)$ \\
Dy-O(3) & $2.409(5)$ & Dy-N(1) & $2.488(7)$ \\
Dy-O(5) & $2.401(5)$ & Dy-N(2) & $2.469(7)$ \\
Dy-O(9) & $2.397(5)$ & Dy-N(3) & $2.496(6)$ \\
Dy-O(7) & $2.419(5)$ & & \\
$\mathrm{Ca}(1)-\mathrm{O}(6 ')$ & $2.446(5)$ & $\mathrm{Ca}(2)-\mathrm{O}(3 \mathrm{w})$ & $2.323(8)$ \\
$\mathrm{Ca}(1)-\mathrm{O}(10)$ & $2.410(5)$ & $\mathrm{Ca}(2)-\mathrm{O}(4 \mathrm{w})$ & $2.323(5)$ \\
$\mathrm{Ca}(1)-\mathrm{O}(1 \mathrm{w})$ & $2.514(5)$ & $\mathrm{Ca}(3)-\mathrm{O}(12)$ & $2.266(5)$ \\
$\mathrm{Ca}(1)-\mathrm{O}(2 \mathrm{w})$ & $2.459(5)$ & $\mathrm{Ca}(3)-\mathrm{O}(5 \mathrm{w})$ & $2.321(5)$ \\
$\mathrm{Ca}(2)-\mathrm{O}(4)$ & $2.299(5)$ & $\mathrm{Ca}(3)-\mathrm{O}(6 \mathrm{w})$ & $2.373(6)$
\end{tabular}

${ }^{a}$ Only crystallographic independent values reported.

Symmetry code for $\mathrm{O}\left(6^{\prime}\right)=-\mathrm{x}, \mathrm{y}-1,-\mathrm{z}+1 / 2$

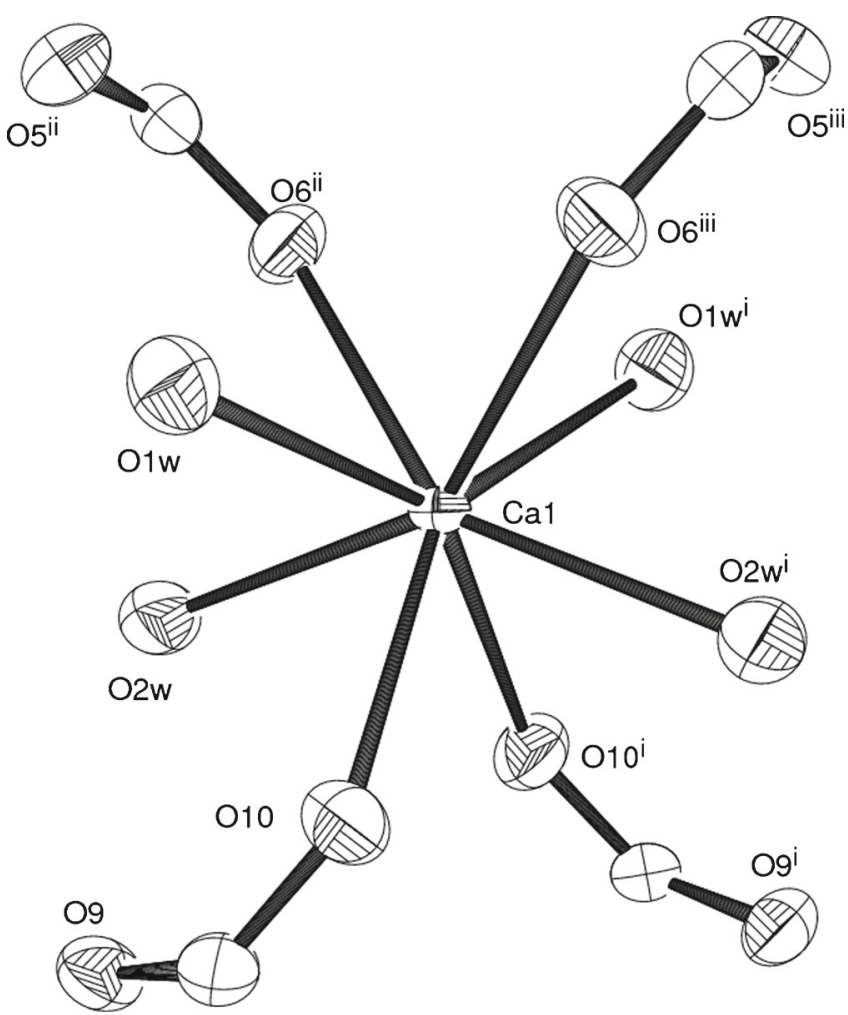

Figure 2. Coordination geometry of calcium ion $\mathrm{Ca}(1)$; symmetry codes (i) $-\mathrm{x}, \mathrm{y},-\mathrm{z}+1 / 2$; (ii) $-\mathrm{x}, \mathrm{y}-1,-\mathrm{z}+1 / 2$; (iii) $\mathrm{x}, \mathrm{y}-1, \mathrm{z}$.

$\mathrm{Ca}(3)-\mathrm{O}$ ones due to larger coordination number for $\mathrm{Ca}(1)$. Moreover, for each independent calcium ion, $\mathrm{Ca}-$ $\mathrm{OH}_{2}$ bond distances appear slightly longer than the Ca$\mathrm{O}$ (carboxylate) ones (table 2), likely due to hydrogen bonds involving the aqua ligands, although $\mathrm{H}$ atoms of water molecules cannot be located on the Fourier map.

The described coordinative interactions give rise to a $3 \mathrm{D}$ porous framework. The crystal packing evidences the lanthanide $\left[\mathrm{Dy}(\mathrm{pyda})_{3}\right]^{3-}$ complexes (located on $a c$ plane) that sandwich the calcium ions and water molecules (figure 4). Thus, calcium ions are trapped between the lanthanide moieties completing their coordination sphere with water molecules. The crystal packing viewed down axis- $b$ (figure 5) shows the formation of a 3D framework of 48 -atom rings comprising six $\left[\mathrm{Dy}(\text { pyda })_{3}\right]^{3-}$ units and six hydrated $\mathrm{Ca}$ ions. The channels are filled by lattice water molecules and correspond to a void volume of $884.7 \AA^{3}$, (ca. $25 \%$ of the unit cell), as calculated by program Platon ${ }^{26}$ by removing the solvent molecules. The present architecture is isostructural to that of the $\mathrm{Tb}$ derivative reported few years ago ${ }^{27}$ although in the present case, based on the Fourier peak height, a half occupancy was assigned to a lattice molecule. 

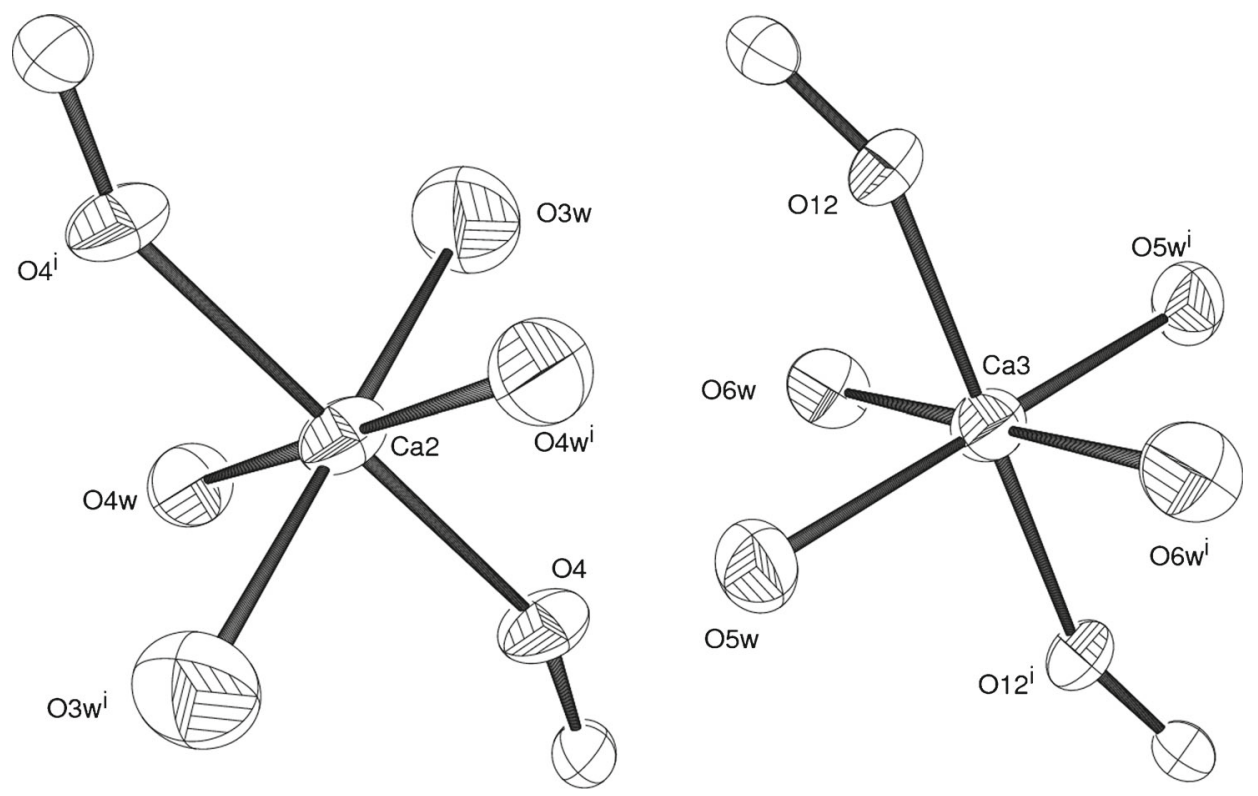

Figure 3. Coordination geometry of calcium ions $\mathrm{Ca}(2)$ and $\mathrm{Ca}(3)$; symmetry codes (i) are $-\mathrm{x}+1,-\mathrm{y}+1,-\mathrm{z}+1 ;$ and $-\mathrm{x},-\mathrm{y}+1,-\mathrm{z}+1$, respectively.

\subsection{Thermal analysis of 1}

Thermogravimetric analysis of the complex indicates that the guest and coordinated water molecules are removed in the range from room temperature to $430.37^{\circ} \mathrm{C}$ as shown in figure s1. Weight loss of $21.03 \%$ is only slightly smaller than the theoretical value (21.67\%), corresponding to the displacement of 11 water molecules. Then, the sample begins to rapidly decompose resulting in $\mathrm{Dy}_{2} \mathrm{O}_{3}$ as final product (table 3).

\subsection{Spectral properties}

Electronic spectrum of complex $\mathbf{1}$ recorded in DMF solution showed two absorption bands at 270 (sh) and
$319 \mathrm{~nm}$ (br) (figure 6). Photoluminescent properties of the $\mathrm{Dy}^{3+}$ complex were investigated at room temperature (figure 7). Emission spectra of the complex display good photoluminescence exhibiting two narrow, sharp and well-separated emission bands. Excitation spectra of the complex reveal that the effective energy absorption occurred in the ultraviolet region $(270-350 \mathrm{~nm})$. Emission spectrum exhibits two intense emission bands at 479 and $573 \mathrm{~nm}$ under excitation wavelength of $321 \mathrm{~nm}$. Dysprosium(III) ion usually shows several emission bands around 480 and $571 \mathrm{~nm}$, which are generally originated from ${ }^{4} \mathrm{~F}_{9 / 2} \rightarrow{ }^{6} \mathrm{H}_{\mathrm{J}}$ transitions. ${ }^{28-30}$ Therefore, the two intense emission bands at $c a .479$ and $573 \mathrm{~nm}$ can be attributable to these transitions $(J=13 / 2$ and $15 / 2)$. This implies that effective energy

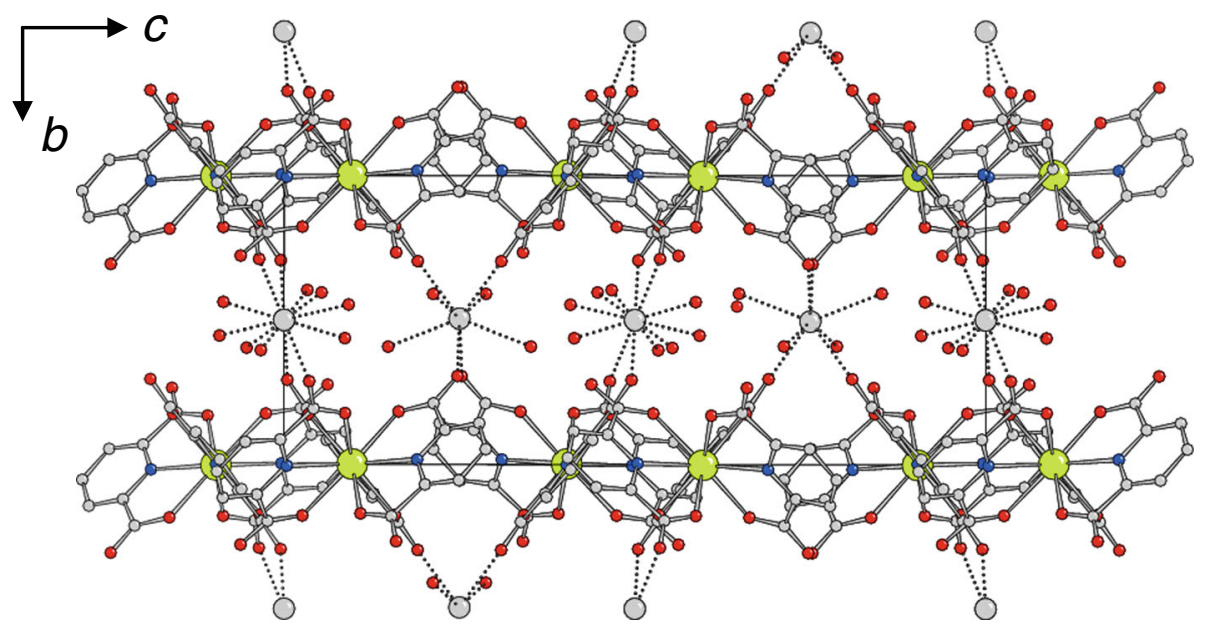

Figure 4. Packing viewed down axis $a$. Lattice water molecules not shown. 


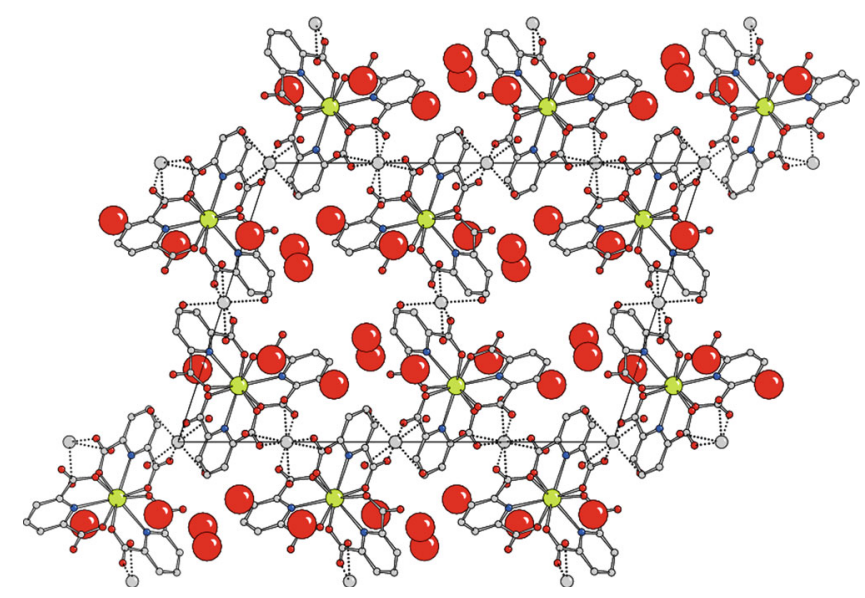

Figure 5. 3D framework viewed down axis $b$ with lattice water molecules (indicated by large spheres).

transfer occurs and the conjugated system between the pyridine-2,6-dicarboxylate and $\mathrm{Dy}^{3+}$ metal ion was formed.

\subsection{DNA binding experiments}

Binding phenomenon of metal complexes with DNA was investigated by electronic absorption spectral technique. Thus, absorption and emission spectra were applied to investigate the interaction of complex 1 with calf thymus DNA (CT-DNA). In general, an intercalative interaction of the aromatic chromophore of the complex and the base pairs of DNA helix is reflected by hypochromism and red shift of charge transfer band. ${ }^{31}$ Absorption spectra of complex $\mathbf{1}$ in the absence and presence of CT-DNA (depicted in figure 8) showed a significant hyperchromism in the charge transfer band at $261 \mathrm{~nm}$, which suggests that there is a strong nonintercalative interaction. Spectral changes of complex 1 observed in the presence of CT-DNA can be exemplified in terms of groove binding. ${ }^{22}$ It is reported that aromatic ring of the molecule closely matches with the helical turn of the CT-DNA groove and the aromatic ring of ligand interacts with DNA in Tris- $\mathrm{HCl}$ buffer through the formation of vander Waal's contacts or hydrogen bonds in DNA grooves.

Binding strength in addition to the type of binding of complex 1 with CT-DNA were examined by evaluating

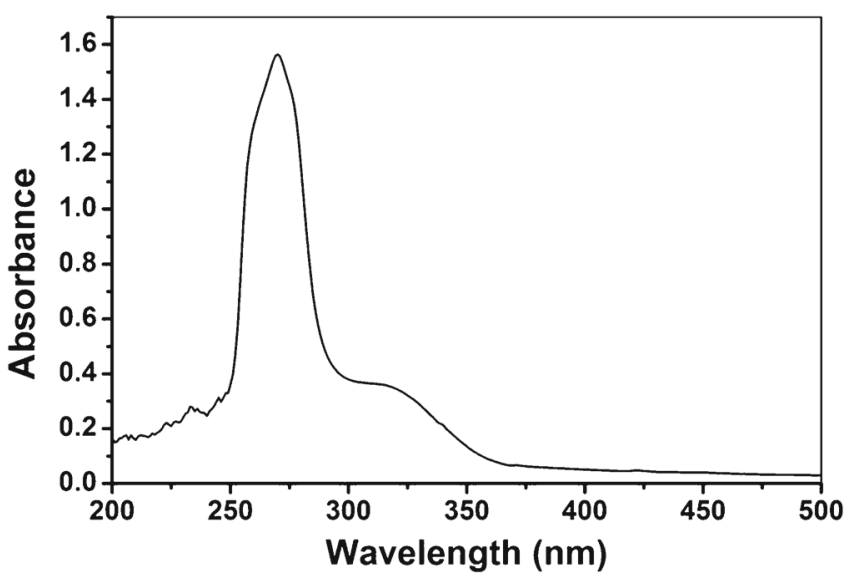

Figure 6. UV spectra of complex 1 in DMF solution with $\lambda_{\max }$ at $270 \mathrm{~nm}(\log \varepsilon=4.20)$ and $319 \mathrm{~nm}(\log \varepsilon=3.54)$.

the apparent association constant, $K_{\mathrm{b}}$ from the spectral titration data using the following equation: ${ }^{31}$

$$
\begin{aligned}
{[\mathrm{DNA}] /\left(\varepsilon_{\mathrm{a}}-\varepsilon_{\mathrm{f}}\right)=} & {[\mathrm{DNA}] /\left(\varepsilon_{\mathrm{b}}-\varepsilon_{\mathrm{f}}\right) } \\
& +1 /\left[K_{\mathrm{b}}\left(\varepsilon_{\mathrm{b}}-\varepsilon_{\mathrm{f}}\right)\right],
\end{aligned}
$$

where [DNA] is the concentration of DNA, $\varepsilon_{\mathrm{f}}, \varepsilon_{\mathrm{a}}$ and $\varepsilon_{\mathrm{b}}$ correspond to the extinction coefficient for the free complex $\mathbf{1}$, for each addition of DNA to the complex $\mathbf{1}$ and for complex $\mathbf{1}$ in the fully bound form, respectively. The apparent association constant $K_{\mathrm{b}}$ for complex 1 was estimated to be $4.08 \times 10^{4} \mathrm{M}^{-1}\left(R^{2}=\right.$ 0.99586 for five points) from [DNA]/( $\left.\varepsilon_{\mathrm{a}}-\varepsilon_{\mathrm{f}}\right)$ versus [DNA] plot (figure 9). This also establishes the presence of groove-binding interaction of complex $\mathbf{1}$ with CT-DNA being the behaviour comparable with the well-established binding agent spermine. ${ }^{32}$

From the viscosity measurements, it was found that there was hardly any effect on the relative viscosity of the DNA solution. This experiment suggests that the interaction mode is groove binding, which gives support to the above results obtained via spectroscopic study. On the other hand, an intercalative interaction would induce a change in the relative viscosity of DNA, since intercalation leads to an increase in the DNA viscosity by lengthening the DNA helix, or non-classical intercalation could bend (or kink) the DNA helix by reducing its effective length and, concomitantly, its viscosity. ${ }^{33,34}$

Table 3. Thermal analysis.

\begin{tabular}{lccc}
\hline Temperature $\left({ }^{\circ} \mathbf{C}\right)$ & Weight loss $(\boldsymbol{\%})$ & Weight loss $(\mathbf{g})$ & Inference \\
\hline $0-97.95$ & 5.879 & 53.709 & 3 water molecules \\
$97.95-167.47$ & 7.24 & 70.565 & 4 water molecules \\
$167.47-430.37$ & 7.907 & 72.237 & 4 water molecules \\
$430.37-651.27$ & 39.432 & 360.24 & After $430^{\circ} \mathrm{C}$ thermal decomposition leads to $\mathrm{Dy}_{2} \mathrm{O}_{3}$. \\
\hline
\end{tabular}




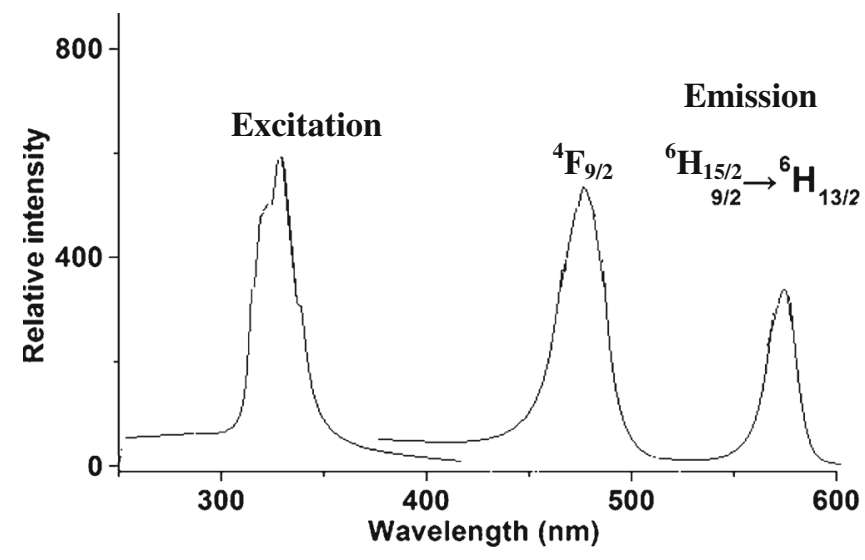

Figure 7. Excitation $\left(\lambda_{\mathrm{ex}}=321 \mathrm{~nm}\right)$ and emission $\left(\lambda_{\mathrm{em}}=\right.$ 479 and $573 \mathrm{~nm}$ ) spectra of $\mathbf{1}$ in solution at room temperature.

Fluorescence intensity of EB bound to CT-DNA at excitation wavelength of $522 \mathrm{~nm}$ decreases by increasing the concentration of complex 1 (figure 10). Binding of the complex 1 with CT-DNA causes the replacement of EB and at the same time induces a decrease of fluorescence intensity of DNA-EB system. Quenching of EB bound to DNA by complex $\mathbf{1}$ is in agreement with the linear Stern-Volmer equation: ${ }^{35}$

$$
I_{0} / I=1+K_{\mathrm{SV}}[Q], \ldots \ldots \ldots \ldots \ldots
$$

where $I_{0}$ and $I$ represent the fluorescence intensities in the absence and presence of quencher, respectively. $K_{\text {sv }}$ is a linear Stern-Volmer quenching constant, $Q$ is the concentration of quencher. The $K_{\mathrm{sv}}$ value calculated from the plot of $I_{0} / I$ versus [complex] (figure 11) was

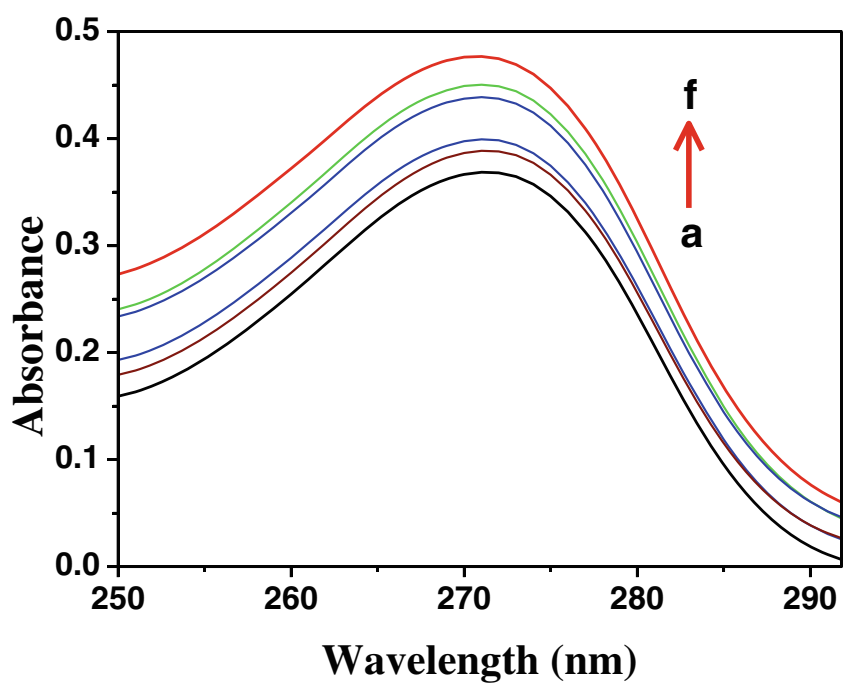

Figure 8. Electronic spectral titration of complex 1 with CT-DNA at $271 \mathrm{~nm}$ in Tris-HCl buffer; [1] = 2.56 $\times 10^{-5}$; [DNA]: (a) 0.0 , (b) $2.50 \times 10^{-6}$, (c) $5.00 \times 10^{-6}$, (d) 7.50 $\times 10^{6}$, (e) $10.0 \times 10^{-6}$, (f) $12.5 \times 10^{-6} \mathrm{~mol} \mathrm{~L}^{-1}$. The arrow denotes gradual increase in DNA concentration.

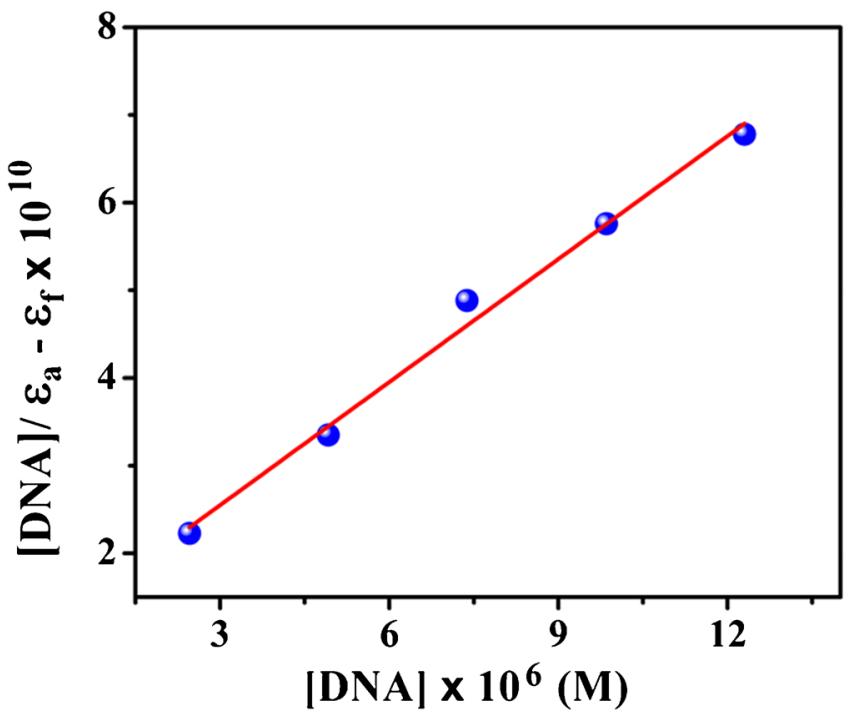

Figure 9. Plot of $[\mathrm{DNA}] /\left(\varepsilon_{\mathrm{a}}-\varepsilon_{\mathrm{f}}\right)\left(\mathrm{M}^{2} . \mathrm{cm}\right) v s[\mathrm{DNA}](\mu \mathrm{M})$ for the absorption titration of CT-DNA with complex 1 in Tris-HCl buffer. Association constant $K_{\mathrm{b}}=4.04 \times 10^{4} \mathrm{M}^{-1}$ ( $R=0.99586, n=5$ points).

found to be $9.1 \times 10^{3}$ ( $R^{2}=0.98905$ for five points), suggesting a significant affinity of 1 towards CT-DNA.

\subsection{Protein (bovine serum albumin) binding experiments}

A similar type of experiment was performed with BSA and complex 1, the only difference being the concentration of BSA that was kept constant throughout the experiment. Figure 12 shows gradual increase in absorbance with increasing concentration of $\mathbf{1}$. In order

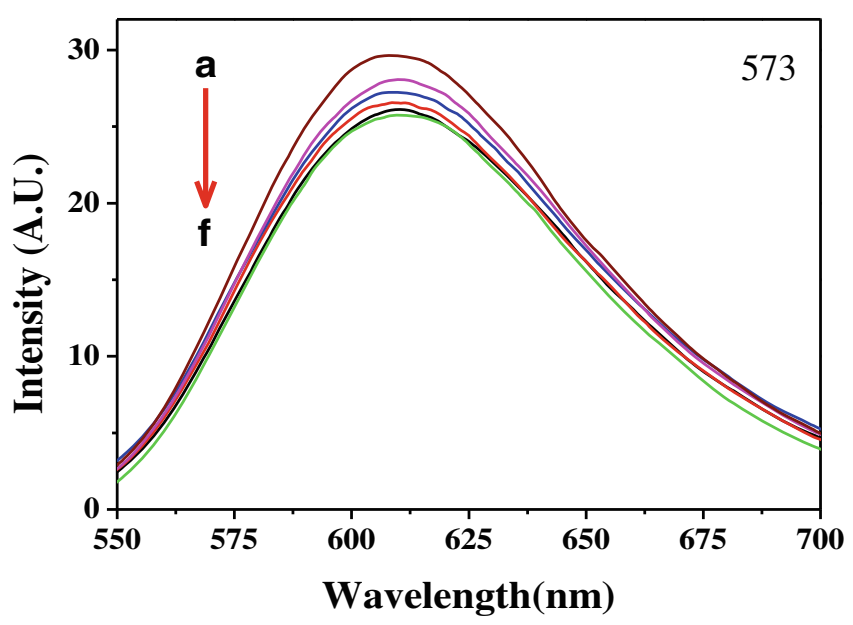

Figure 10. Emission spectra of the CT-DNA-EB system in Tris-HCl buffer upon titration with complex 1 . $\lambda_{\text {ex }}=522 \mathrm{~nm}$; $[\mathrm{EB}]=9.6 \times 10^{-5},[\mathrm{DNA}]=1.58 \times 10^{-5} ;[\mathbf{1}]=$ (a) 0.0, (b) $1.28 \times 10^{-5}$, (c) $2.56 \times 10^{-5}$, (d) $3.84 \times 10^{-5}$, (e) $5.12 \times$ $10^{-5}$, (f) $6.40 \times 10^{-5} \mathrm{~mol} \mathrm{~L}^{-1}$. The arrow denotes gradual increase in complex concentration. 




Figure 11. Plot of $I_{0} / I$ vs. [complex] for the titration of CT-DNA-EB system with complex $1 ; k=9.1 \times 10^{3}(R=$ $0.989, n=5$ points).

to confirm that the observed absorption change in the spectrum was not due to experimental errors, a baseline correction was performed for all the measurements. The results clearly indicate that an interaction occurs between complex 1 and BSA $^{36}$ and the apparent binding constant $\left(K_{\text {ap }}\right)$ can be determined by using equation $(3)::^{37}$

$$
\begin{aligned}
1 /\left[A_{\mathrm{obs}}-A_{0}\right]= & 1 /\left[A_{\mathrm{c}}-A_{0}\right]+1 / K_{\mathrm{ap}}\left(A_{\mathrm{c}}-A_{0}\right) \\
& \times[\text { complex }], \ldots \ldots \ldots \ldots
\end{aligned}
$$

where $A_{\text {obs }}$ is the observed absorbance of the solution containing different concentrations of complex $\mathbf{1}, A_{0}$

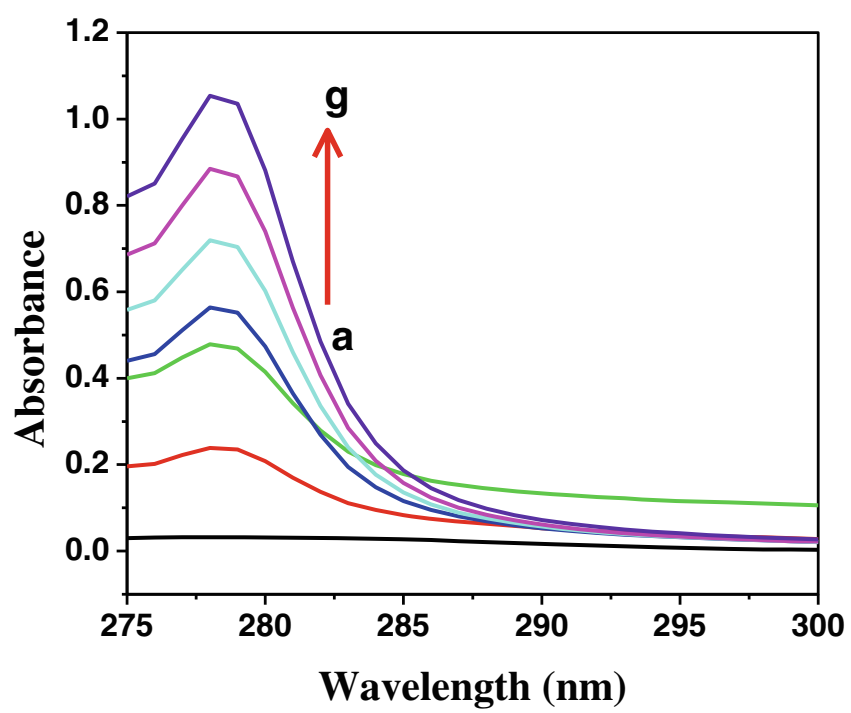

Figure 12. UV-Vis titration of BSA by increasing the concentration of $\mathbf{1}$ at $278 \mathrm{~nm}$; [complex 1] = (a) 0.0 , (b) $1.27 \times$ $10^{-5}$, (c) $2.54 \times 10^{-5}$, (d) $3.82 \times 10^{-5}$, (e) $5.09 \times 10^{-5}$, (f) $6.36 \times 10^{-5}$ and $(\mathrm{g}) 7.64 \times 10^{-5} \mathrm{M}$.



Figure 13. Plot of $1 /\left[A-A_{0}\right]$ vs $1 /[$ complex $]$ for the titration of BSA with complex $\mathbf{1}$ in aqueous medium.

and $A_{\mathrm{c}}$ are the absorbances at $280 \mathrm{~nm}$ of BSA and of the complex, respectively. From the plot of $1 /\left[A_{0}-A\right] / \mathrm{A}$ vs. $1 /$ [complex 1] (figure 13), $K_{\text {ap }}$ was determined to be $3.49 \times 10^{3}\left(R^{2}=0.94287\right.$ for four points). The value of the binding constant $K_{\text {ap }}$ indicates a considerably strong affinity of 1 to BSA.

Fluorescence intensity of BSA at excitation wavelength of $282 \mathrm{~nm}$ shows a decrease with increase in concentration of complex 1 (figure 14). Quenching of BSA by complex 1 also follows the linear Stern-Volmer equation (2). The $K_{\mathrm{sv}}$ value estimated from the plot of $I_{0} / I$ vs. [complex] (figure 15) is considerably high and it was calculated to be $3.01 \times 10^{5}\left(R^{2}=0.9913\right.$ for

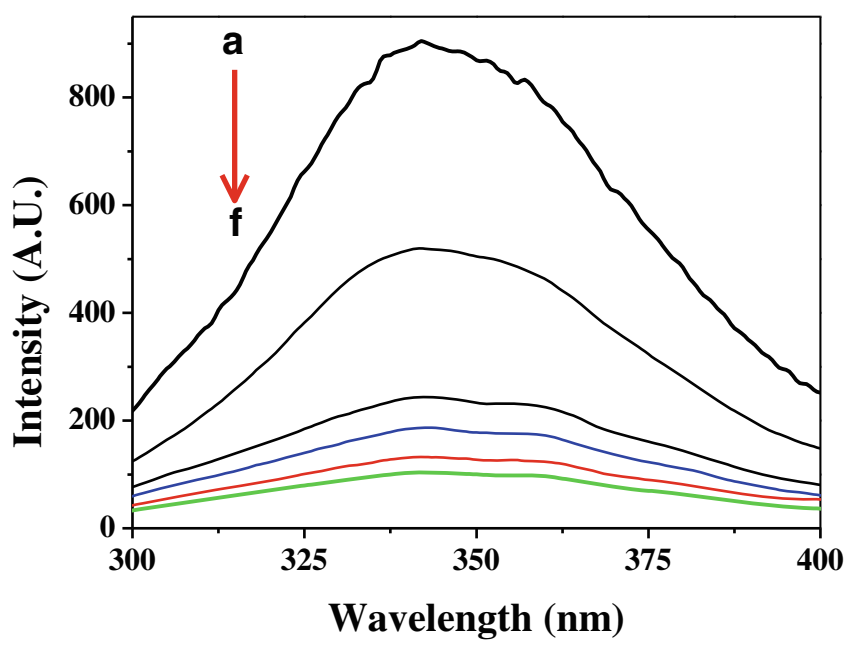

Figure 14. Fluorescence quenching titration of BSA by increasing the concentration of $\mathbf{1}$. [complex] = (a) 0.0 , (b) $1.27 \times 10^{-5}$, (c) $2.54 \times 10^{-5}$, (d) $3.82 \times 10^{-5}$, (e) $5.09 \times$ $10^{-5}$ and (f) $7.64 \times 10^{-5} \mathrm{M}$. 


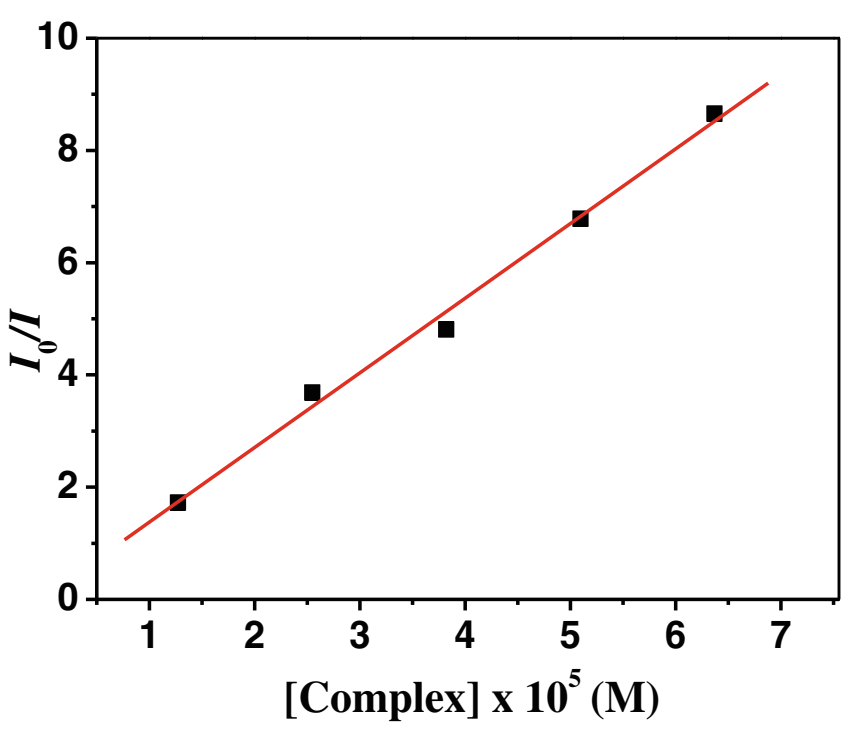

Figure 15. Stern-Volmer plot of $I_{0} / I$ vs. concentration of complex 1 in the titration of BSA. [complex] $=0.0,1.27 \times$ $10^{-5}, 2.54 \times 10^{-5}, 3.82 \times 10^{-5}, 5.09 \times 10^{-5}, 6.36 \times 10^{-5}$ and $7.64 \times 10^{-5} \mathrm{M}$.

five points), indicating a strong affinity of complex $\mathbf{1}$ to BSA with formation of a complex-BSA adduct.

\section{Conclusion}

Several hydrothermally synthesized lanthanide complexes and coordination polymers have been reported so far highlighting different functionalities and properties. $^{38-45}$ Physical and chemical properties of the lanthanide ions and their chelates have provided a source to investigate various biological systems employing their luminescence. In this article, we have described a newly designed dysprosium-based metalorganic coordination framework comprising calcium ions that proved to be a good groove binding agent by studying its interaction with calf thymus DNA (CT-DNA). In addition, spectroscopic study proved the interaction of dysprosium complex with BSA indicating the formation of a complex-BSA adduct. Although some complexes have been postulated to selectively bind to DNA, with contributions from electrostatic attraction, groove and intercalative binding ${ }^{42-45}$ the concurrent properties manifested by the present lanthanide complex to interact with CT-DNA and BSA ${ }^{46,47}$ have been less frequently encountered in the literature.

\section{Supplementary Information}

Crystallographic data of complex $\mathbf{1}$ has been deposited with the Cambridge Crystallographic Data Centre with
CCDC no. 873072. Copies of this information can be obtained free of charge from The Director, CCDC, 12 Union Road, Cambridge, CB2 IEZ, UK (Fax: +44-1223-336033; Email: deposit@ccdc.cam.ac.uk or http://www.ccdc.cam.ac.uk). TGA diagram and FTIR spectrum (figures s1 and s2) are available as supporting information (see www.ias.ac.in/chemsci).

\section{Acknowledgements}

Financial support from the University Grants CommissionDepartment of Atomic Energy-Consortium for Scientific Research (UGC-DAE-CSR), Kolkata Centre, India is acknowledged. We thank (EPSRC) and the University of Reading for providing funds for the Oxford $\mathrm{X}$-Calibur system. E Zangrando thanks MIUR-Rome (PRIN 2007HMTJWP_002) for financial support.

\section{References}

1. Ockwig N W, Delgado-Friedrichs O, O'Keeffe M and Yaghi M O 2005 Acc. Chem. Res. 38176

2. Gao H, Yi L, Zhao B, Zhao X, Cheng P, Liao D and Yan S 2006 Inorg. Chem. 455980

3. Champness N R 2006 Dalton Trans. 877

4. Moulton B and Zaworotko J M 2001 Chem. Rev. 101 1629

5. Kitagawa S, Kitaura R and Noro S 2004 Angew. Chem. Int. Ed. $\mathbf{4 3} 2334$

6. Janiak C 2003 Dalton Trans. 2781

7. Parker D 2000 Coord. Chem. Rev. 205109

8. Spichal Z, Hegrova B, Moravec Z, Pinkas J and Necas M 2011 Polyhedron 301620

9. Guo X, Zhu G, Li Z, Sun F, Yang Z and Qiu S 2006 Chem. Commun. 3172

10. Liu W, Jiao T, Li Y, Liu Q, Tan M, Wang H and Wang L 2004 J. Am. Chem. Soc. 1262280

11. Binnemans K 2009 Chem. Rev. 1094283

12. Bunzli J C G and Piguet C 2005 Chem Soc Rev. 341048

13. Ghosh K S and Bharadwaj P K 2005 Inorg. Chem. 44 3156

14. Patra A, Sen B, Sarkar S, Pandey A, Zangrando E and Chattopadhyay P 2013 Polyhedron 31156

15. Chakraborty R, Chatterjee S, Sarkar S and Chattopadhyay P 2012 J. Biomater. Nanobiotech. 3462

16. Dey S, Sarkar S, Evans H S and Chattopadhyay P 2011 Trans. Met. Chem. 36631

17. Patra A, Sarkar S, Mukherjee T, Zangrando E and Chattopadhyay P 2011 Polyhedron 302783

18. Sarkar S, Sen S, Dey S, Zangrando E and Chattopadhyay P 2010 Polyhedron 293157

19. Otwinowski $Z$ and Minor W 1997 Processing of X-ray diffraction data collected in Oscillation Mode, Methods in enzymology, Vol. 276, Macromolecular Crystallography, part A, 307-326, Carter, Jr. CW and Sweet RM Eds. (New York: Academic Press)

20. Sheldrick G M 2008 Acta Cryst. A 64112

21. Farrugia L J 1999 J. Appl. Crystallogr. 32837 
22. Marmur J 1961 J. Mol. Biol. 3208

23. Reichmann M E, Rice S A, Thomas C A and Doty P 1954 J. Am. Chem. Soc. 763047

24. Barton J K, Goldberg J M, Kumar C V and Turro N J 1986 J. Am. Chem. Soc. 1082081

25. Huang Y G, Yuan D Q, Gong Y Q, Jiang F L and Hong M C 2008 J. Mol. Struct. 87299

26. Spek A L 1990 Acta Crystallogr. Sect A. 4634

27. Song Y S, Yan B and Chen Z X 2004 J. Solid State Chem. 1773805

28. Li M, Yuan L, Li H and Sun J 2007 Inorg. Chem. Commun. 101281

29. Yan B, Zhou B and Wang Q M 2006 Appl. Organomet. Chem. 20835

30. An Y, Liu S D, Deng S Y, Ji L N and Mao Z W 2006 J. Inorg. Biochem. 1001586

31. Pyle A M, Rehmann J P, Meshoyrer R, Kumar C V, Turro N J and Barton J K 1989 J. Am. Chem. Soc. 111 3051

32. Strekowski L, Harden D B, Wydra R L, Stewart K D and Wilson W D 1989 J. Mol. Recognit. 2158

33. Satyanarayana S, Dabrowiak J C and Chaires J B 1992 Biochemistry 319319

34. Satyanarayana S, Dabrowiak J C and Chaires J B 1993 Biochemistry 322573
35. Stern O and Volmer M 1919 Phys. Z. 20183

36. Chen C, Qi X and Zhou B 1997 J. Photochem. Photobiol. A: Chem. 109155

37. Kathiravan A and Renganathan R 2009 Polyhedron 28 1374

38. Kapoor P, Singh R V and Fahmi N 2012 J. Coord. Chem. $\mathbf{6 5} 262$

39. Sharif S, Sahin O, Khan I U and Buyukgungo O $2012 \mathrm{~J}$. Coord. Chem. 651892

40. Liu Y, Zhang K, Lei R, Liu J, Zhou T and Yang Y Z 2012 J. Coord. Chem. 652041

41. Wang J J, Zhang L P, Huang L and Chen J $2012 \mathrm{~J}$. Coord. Chem. 653274

42. Yunma D, Guo H F, Qin L, Pan Y, Lu K and Liu J Q 2012 J. Coord. Chem. 653424

43. Chowdhury S R, Selim M, Chatterjee S, Igarashi S, Yukawa Y and Mukherjea K K 2012 J. Coord. Chem. 65 3469

44. Wang M F, Yang Z Y, Liu Z C, Li Y, Li T R, Yan M H and Cheng X Y 2012 J. Coord. Chem. 653805

45. Che G, Wang X, Liu C, Chen J, Wang S and Li X 2012 J. Coord. Chem. $\mathbf{6 5} 4185$

46. Chen W, Chen Y, Liu W, Lei T, Gao Q, Kim D, Su D, Li W and Li Y 2012 J. Coord. Chem. 654430

47. Xu J and Chen M D 2013 J. Coord. Chem. 66509 